\title{
CENTRAL AND LOCAL ADMINISTRATION IN WARTIME: THE PARTICIPATION OF THE GREAT PERM IN THE FORMATION OF THE PEOPLE'S ARMY AGAINST THE TUSHINS IN LATE 1608 - EARLY 1609
}

\author{
Natalia V. Rybalko \\ Volgograd State University, Volgograd, Russian Federation
}

\begin{abstract}
Introduction. The process of forming zemstvo militias in defense of Tsar V.I. Shuisky and the whole country in the Moscow state began in late 1608 - early 1609 at the height of the confrontation between the Moscow and Tushino political regimes. The article examines the role of the government of V.I. Shuisky in governing the state, in particular, Perm the Great, and the participation of this remote region in military affairs. Researchers have merely addressed this aspect and come to opposite judgments. Methods and materials. We have a large complex of zemstvo correspondence at our disposal, preserved in the archives of the Solikamsk district court. Many documents were published as early as the $1^{\text {th }}$ century but their detailed analysis was not carried out. Clarification of the dating and reconstruction of information both about the documents that have come down to us and the documents only mentioned, the introduction of unpublished acts into circulation allows us to restore the true picture of events. A fund-by-fund study was carried out by the method of mutual correspondence of documents. Analysis. In the course of the research, it was revealed that the first of the initiative documents that reached the Great Perm about the support of Tsar V.I. Shuisky in military affairs were formal replies from Galich and Vologda. Perm clerks F.P. Akinfov and N. Romanov received them on December 15, 1608, and they were read by the whole world. Active gatherings of military men in Perm the Great began only after January 1, 1609, when a list with a sovereign letter was brought to the Galicians. At that time the territory of Perm the Great consisted of 3 counties: Cherdyn, Solikamsk, Kaigorod. By January 10, 1609, the first gathering ended and 20 military men of Soli Kamskaya left on the way to Moscow. In Kaigorodok they were robbed, carts and weapons were taken away, the headman and worldly people did not give new carts in the ship's hut, as a result they could not continue their journey, and there was a delay. In February, together with 20 Kaigorod military men, they moved on. On March 1, 1609, 50 Cherdynians left Perm the Great. The war men of Perm the Great came to Vologda at the end of March 1609 and were assigned to further service in the militia. Results. The article shows that the complete blockade of Moscow in the fall of $1608 \mathrm{did}$ not materialize. However, regular communication between Moscow and the cities of Pomorie was disrupted. For the period from January 1 to mid-April 1609 in Perm the Great on behalf of Tsar V.I. Shuisky received 5 decree letters from the Novgorod discharge order on the issue of collecting military men and sending them to Moscow to fight the Tushin people, and 3 executive orders from the Novgorod quarter order on the sovereign's treasury and sending bread to Siberian cities for salaries to service people. These documents were direct orders of the supreme power and were perceived by the order people in Perm the Great as a guide to action. In addition to them, the zemstvo correspondence with the nearest cities made it possible to find out news about the military events taking place in the country. The clerk Fedor Petrovich Akinfov and the clerk Naum Romanov tried to carry out the orders of the tsar, but they did not always manage to do this as quickly as was expected of them. There is no reason to consider the resulting delay in the dispatch of the Perm military men as unwillingness of the orderly people appointed from Moscow for 2-3 years to participate in the support of Tsar V. Shuisky and the Zemstvo movement. The delay is more likely due to the lack of clear administrative management at the local level: if in Soli Kamskoy they quickly responded to the request and sent 20 military men, then in Kaigorodok they began to put up obstacles not only in $\vec{\nabla}$ the form of robbery, but also at the level of mundane self-government, not obeying the regional leadership.

$\overrightarrow{\widetilde{S}}$ Key words: history of Russia, Time of Troubles, $17^{\text {th }}$ century, 1608, 1609, zemstvo militia, charters, the Great Perm.

Citation. Rybalko N.V. Central and Local Administration in Wartime: The Participation of the Great Perm in the Formation of the People's Army Against the Tushins in Late 1608 - Early 1609. Vestnik Volgogradskogo gosudarstvennogo universiteta. Seriya 4. Istoriya. Regionovedenie. Mezhdunarodnye otnosheniya [Science Journal of Volgograd State University. History. Area Studies. International Relations], 2021, vol. 26, no. 5, pp. 84-96. (in Russian). DOI: https://doi.org/10.15688/jvolsu4.2021.5.7
\end{abstract}




\title{
ЦЕНТРАЛЬНОЕ И МЕСТНОЕ УПРАВЛЕНИЕ В УСЛОВИЯХ ВОЕННОГО ВРЕМЕНИ: УЧАСТИЕ ПЕРМИ ВЕЛИКОЙ В ФОРМИРОВАНИИ ОПОЛЧЕНИЯ ПРОТИВ ТУШИНЦЕВ В КОНЦЕ 1608 - НАЧАЛЕ 1609 ГОДА
}

\author{
Наталия Владимировна Рыбалко \\ Волгоградский государственный университет, г. Волгоград, Российская Федерация
}

\begin{abstract}
Аннотация. Введение. В конце 1608 - начале 1609 г. в Московском государстве в разгар противостояния Московского и Тушинского политических режимов начался процесс формирования земских ополчений в защиту государя В.И. Шуйского и всей страны. В статье исследуется роль правительства В.И. Шуйского в управлении государством, в частности, в Перми Великой, и участие этого отдаленного региона в ратном деле. Исследователи данный аспект только затрагивали и пришли к противоположным суждениям. Meтоды u материалы. В нашем распоряжении имеется большой комплекс земской переписки, отложившийся в архиве Соликамского уездного суда. Многие документы были опубликованы еще в XIX веке. Но детального их анализа не проводилось. Уточнение датировки и реконструкция информации как о дошедших до нас, так и о только упоминаемых документах, введение в оборот неопубликованных актов позволяет восстановить истинную картину событий. Проведено пофондовое изучение методом взаимного соответствия документов. Анализ. В то время территория Перми Великой состояла из трех уездов: Чердынского, Соликамского, Кайгородского. Первыми из дошедших в Пермь Великую инициативными документами о поддержке царя В.И. Шуйского в военном деле были отписки из Галича и Вологды. Пермские приказные люди Ф.П. Акинфов и Н. Романов получили их 15 декабря 1608 г., читали всем миром. Но активные сборы ратных людей в Перми Великой начались только после 1 января 1609 г., когда был привезен список с государевой грамоты галичанам. К 10 января 1609 г. первые сборы закончились и 20 ратных людей Соли Камской вышли по дороге к Москве. В Кайгородке их ограбили, забрали подводы и оружие, в судной избе староста и мирские люди новых подвод не дали, в результате чего продолжить свой путь они не могли, и возникло промедление. В феврале вместе с 20 кайгородскими ратными людьми они двинулись дальше, 1 марта 1609 г. из Перми Великой вышли 50 чердынцев. Ратные люди Перми Великой в количестве 96 человек пришли к Вологде в конце марта 1609 г. и были определены на дальнейшую службу в ополчение. Результаты. В статье показано, что полной блокады Москвы осенью 1608 г. не осуществилось. Однако регулярная связь Москвы с городами Поморья была нарушена. За период с 1 января и до середины апреля 1609 г. в Перми Великой от имени царя В.И. Шуйского были получены 5 указных грамот из Новгородского разрядного приказа по вопросу сбора ратных людей и отправки к Москве для борьбы с тушинцами, и 3 указные грамоты из Новгородского четвертного приказа о государевой казне и отправке хлеба в сибирские города на жалованье служилым людям. Эти документы являлись прямыми распоряжениями верховной власти и воспринимались приказными людьми в Перми Великой как руководство к действию. В дополнение к ним земская переписка с ближайшими городами позволяла узнать новости о происходивших в стране военных событиях. Приказный человек Федор Петрович Акинфов и подьячий Наум Романов старались исполнять распоряжения царя, но им это не всегда удавалось сделать так быстро, как от них ожидалось. Нет оснований считать возникшее промедление с отправкой пермских ратных людей нежеланием приказных людей, назначавшихся из Москвы на 2-3 года, участвовать в поддержке царя В. Шуйского и земского движения. Промедление скорее связано с отсутствием четкого административного управления на местном уровне: если в Соли Камской быстро отреагировали на запрос и выставили ратных людей, то в Кайгородке стали чинить препятствия не только в виде разбоя, но и на уровне мирского самоуправления, не подчиняясь региональному руководству.

Ключевые слова: история России, Смутное время, XVII в., 1608 г., 1609 г., земское ополчение, грамоты, Пермь Великая.
\end{abstract}

Цитирование. Рыбалко Н. В. Центральное и местное управление в условиях военного времени: участие Перми Великой в формировании ополчения против тушинцев в конце 1608 - начале 1609 года // Вестник Волгоградского государственного университета. Серия 4, История. Регионоведение. Международные отношения. - 2021. - Т. 26, № 5. - С. 84-96. - DOI: https://doi.org/10.15688/jvolsu4.2021.5.7 
Введение. Система центрального управления Российского государства, пережившая первое серьезное испытание в царствование самозванца Лжедмитрия I, вновь проверялась на прочность в период противостояния Тушинского и Московского политических режимов в 1608-1610 годах. С началом активных военных действий со стороны приверженцев самозванца Лжедмитрия II осенью 1608 г. напряжение в обществе нарастало. Поражение правительственных войск у с. Рахманцева, Ростова, их блокирование тушинцами в Москве, Смоленске, Великом Новгороде, Нижнем Новгороде, Казани, Переяславле Рязанском, Коломне, Троице-Сергиевом и Иосифо-Волоколамском монастырях к концу ноября 1608 г., как показало исследование И.О. Тюменцева [21, с. 219-268], способствовало развитию ситуации не в пользу Василия Шуйского. Многие города переходили на сторону самозванца или с верой в его обещания, или вынужденно, спасая свою жизнь и имущество.

Особая ситуация сложилась в городах Вятской земли, Перми Великой, часто относимых к городам Поморья. Отдаленное от эпицентра военных действий расположение не позволяло приказным людям и воеводам, управлявшим этими территориями, оперативно реагировать на происходившие события и, как следствие, активно участвовать во многих из них. Но именно эти города способствовали формированию земского ополчения, которое, собравшись весной 1609 г., оказало значительную поддержку правительственным войскам в борьбе с тушинцами. Как же осуществлялось управление страной в начальный период складывания земского ополчения? Можно ли говорить о полной парализации власти правительства В.И. Шуйского в декабре 1608 марте 1609 года? Что стало решающим фактором для начала активных действий по сбору ратных людей против тушинцев в одной из отдаленных территорий Московского государства - Перми Великой?

Историография. В литературе неоднократно рассматривался вопрос организации и характера земского движения, в основе которого лежит переписка между городами. В связи с этим исследователи высказывали свои суждения относительно роли в организации земского движения правительства
В.И. Шуйского. С.Ф. Платонов отметил: «Трудно с точностью измерить то значение, какое имело для устройства дела на севере... воздействие правительства и московских людей», но был уверен в том, что «северные города один за другим восстают против тушинцев не по симпатии к Шуйским и не по уверенности, что тушинский Дмитрий самозванец и вор - восстают они за порядок против нарушителей его» [10, с. 289]. По предположению историка, это движение началось с Устюга, который вступил в переписку с Вологдой. И зимой 1608-1609 гг. «не одна земская самодеятельность вносила правильную организацию во взаимные отношения северных городов... Правительство Шуйского с своей стороны не уставало возбуждать Поморье и даже пыталось руководить военными действиями не только на Вологде, но и вообще на Севере» $[11$, с. 300$]$. П.Г. Любомиров пришел к заключению, что борьбу против тушинцев организовал и развил специально созданный в Нижнем Новгороде городской совет «совершенно самостоятельно, без какихлибо указаний из Москвы» [5, с. 51]. По мнению И.С. Шепелева, народно-освободительное движение, под которым он подразумевал «сопротивление народных масс» (крестьян и посадского населения) началось не по сигналу властей правительства Шуйского, а стихийно, снизу, на огромной территории, в нескольких местах, малыми группами. Одним из первых было освобождение Луха вне зависимости от действий в Нижнем Новгороде [24, с. 299, 300]. И.О. Тюменцев, обстоятельно изучив движение Лжедмитрия II, оспорил выводы И.С. Шепелева, в частности, о параличе власти В.И. Шуйского и его окружения после Рахманцевского сражения и отсутствии у правительства реального представления о ситуации в стране. И.О. Тюменцев согласился с выводами Н.И. Костомарова, Л.Б. Генкина и Ю.С. Васильева о том, что движение против тушинцев началось в Галиче. Проведя комплексный анализ грамот царя В.И. Шуйского за период с апреля по июнь 1609 г., перехваченных тушинцами и отложившихся в архиве Я. Сапеги, исследователь пришел заключению, что московские власти «достаточно чутко реагировали на изменение ситуации в стране и пытались руководить отрядами своих сторонников» $[20$, с. $162 ; 21$, с. 389$]$. По мнению 
В.Н. Козлякова, «в городах и уездах сами стали решать свою судьбу», а царь В.И. Шуйский «мог только наблюдать за этой самодеятельностью внутри государства» [4, с. 181].

Методы и материалы. В составе коллекции № 122 «Соликамские акты» Архива Санкт-Петербургского института истории РАН отложились документы не только местного уровня по истории Перми Великой, но и указные грамоты царя, земская переписка между городами периода начала формирования ополчения. В разгар военных действий осени 1608 - весны 1609 г. регулярное прямое сообщение с Москвой было нарушено, грамоты не всегда доставлялись своевременно в пункты назначения, потому быстро получила распространение практика изготовления списков с грамот и их отправка по цепочке в соответствии с существовавшим ямским сообщением. Ситуация осложняется тем, что, в отличие от указных грамот царя Василия Шуйского, составленных в московских приказах и точно датированных, многие документы земской переписки не имеют указания на время их написания. Материалы Соликамского архива при их сплошном просмотре дают возможность выявить информацию о несохранившихся документах по их упоминаниям методом взаимного соответствия документов, датировка грамот позволяет уточнить время происходивших событий и взаимосвязь между ними. Выяснение места составления грамот по фамилиям дьяков и по аналогии дает возможность реконструировать приказное делопроизводство и систему управления, механизм реализации правительственной политики в отдельных регионах.

Несмотря на то что большая часть документов Соликамского архива была опубликована еще в XIX в., анализ управленческой политики В.И. Шуйского в конце 1608 - начале 1609 г. исследователями специально не проводился. Неопубликованные документы, которые были оценены в XIX в. как имеющие второстепенное значение, помогают глубже разобраться с тем, что реально происходило в Перми Великой, и внести корректировку в сложившиеся общепринятые в историографии суждения.

Анализ. Территория Перми Великой в начале XVII в. состояла из трех уездов: Чердынского, Соликамского, Кайгородского. До
1610 г. института воеводства в Перми Великой не было, управление осуществлял приказный человек и подьячий [16]. Приказная изба располагалась в Чердыни.

В Соликамских бумагах периода правления В.И. Шуйского наиболее ранними из отложившихся документов, касающихся политического вопроса - противостояния самозванцу Лжедмитрию II - являются две отписки. Первая составлена в Галиче от князей, дворян, детей боярских, посадских людей и крестьян черных волостей и была адресована К.Д. Строганову. Галичане начали ее словами: «По государеву цареву и великого князя Василия Ивановича всея Русии указу». При этом ссылка на какую-либо конкретную грамоту от В.И. Шуйского отсутствует, однако использованная в начальном протоколе документа формула свидетельствует о реализации правительственной инициативы, а не земской. Такие фразы безосновательно в отписках не появлялись - это видно при сравнении с другими отписками изучаемого фонда. Документ не датирован, но известно, что он был получен в Тотьме 1 ноября 1608 года. С учетом того, что между Галичем и Тотьмой было примерно 2 дня пути, датировать составление отписки можно 29 октября 1608 года. А через 2 дня, 1 ноября, в Галиче была признана власть самозванца, продержавшаяся до 23 ноября 1608 г. - дня, когда в Галиче против тушинцев было поднято восстание [20, № 350, с. 468; 21, c. 388].

Вторая отписка из Вологды в Тотьму характеризует события, произошедшие месяцем позже - 29 ноября 1608 г.: погром Вологды людьми Яна Сапеги, после чего в Вологде произошло восстание и переход на сторону Василия Шуйского. Документ написан вологодским посадским земским целовальником Т. Лягушкиным «с товарищи» от имени посадских, волостных людей и черни по горячим следам событий и был привезен в Тотьму 1 декабря 1608 года. С учетом расстояния между Вологдой и Тотьмой в 2 дня пути, этот документ можно датировать 30 ноября 1608 года.

Обе отписки содержат призыв оставаться верными В.И. Шуйскому, собрать ратных людей и отправить к Галичу и Вологде на помощь, а также «ссылаться меж собя по городам» (Устюг, Соль Вычегодская, Вятка, все 
Подвинье и Пермь Великая) «самим для ратных дел». Эти документы дошли до нас в списках в виде приложений к отписке устюжан к вычегодцам от 4 декабря 1608 г. и были доставлены в Соль Вычегодскую 5 декабря 1608 г., отправлены к Вычегде и на Вымь 6 декабря 1608 года. В Перми Великой эти отписки были получены 15 декабря 1608 г. как приложение к грамоте от приказного человека Поспела Извольского из Соли Вычегодской от 6 декабря 1608 г. с призывом собирать ратных людей в поход на помощь государю. Вместе с тем пересылались списки с устюжских, тотемских, вычегодских грамоток, где описывались события, происходившие в центре страны: измены отдельных людей и городов, погромы и разорения, наносимые литовскими войсками и русскими сторонниками самозванца Лжедмитрия II $[1$, № 109, с. 139; № 115, c. 144 ; 2 , № 89 , c. 181 ; № 91, c. 184; № 102, c. 199; и др.]. Изучение вопросов мотивации показало, что в городах Галич, Вологда произошла актуализация жизненной задачи - paзорение жилья, пленение детей и жен. Это стало значительным толчком для начала земского движения [12, с. 388].

Из Перми Великой ответили в Соль Вычегодскую в тот же день, 15 декабря 1608 г., что полученные отписки «во всем народе чли» и выражают готовность дать ратных людей, как соберутся, и отправить в Москву денежную таможенную и кабацкую казну и за ратных людей деньги за предыдущий год. В 1607/08 г. из Москвы был запрос прислать деньги на 1608 г. вместо ратных людей [1, № 115, с. 144].

Также в Пермь Великую дошел список с отписки устюжан к вычегодцам от 30 ноября 1608 г. [2, № 89, с. 181-183], из текста которой пермичи узнали об устном рассказе крестьянина Устюжского уезда городка Брусенец Митки Седлова о получении ими в городке грамоты царя В.И. Шуйского из Москвы 29 ноября 1608 года. Эта грамота была отправлена, с его слов, «в Галич, Кострому, Поморские города, на Вагу и в Колмогоры», и в ней говорилось о том, что князь М.В. Скопин-Шуйский с новгородцами, псковичами и немцами погромил Тушино. Эту сообщаемую информацию И.О. Тюменцев оценил как слухи, так как сведения о действиях войск М.В. Скопин-Шуйского и Ф.И. Шереметьева не соответствовали реальной действительности [21, с. 388]. Р.Г. Скрынников отметил факт того, что царь Василий в это время прибегал к хитрости: изготавливались ложные грамоты от Скопина, в которых содержались «фантастические сведения» о его походах [18, c. 316]. Митка Седлов рассказал также о том, что в Тотьму к Козме Строганову из Галича прислана государева грамота о сборе ратных людей. Нет оснований сомневаться в подлинности сообщаемой информации, тем более что грамота галичан К.Д. Строганову нам известна. А поскольку, как мы знаем, она начинается отсылкой к государеву указу, крестьянин и назвал ее «государевой грамотой». В этой устюжской отписке от 30 ноября 1608 г. [2, № 89, с. 181-183] содержится важное суждение о роли государевых грамот в принятии решения. В частности, когда устюжане сомневались, присягнуть ли «царю Дмитрию» после получения грамоты от Никиты Пушкина из Вологды, то насторожило их то, что «от государева лица («царя Дмитрия». - Н. Р.) к нему (Никите. - Н. Р.) не писано». Никакие слухи не могли сравниться с тем действием, которое имели государевы грамоты.

Таким образом, первые инициативные документы от галичан и вологодцев с призывом собирать ратных людей в ополчение на помощь государю В.И. Шуйскому имели широкий резонанс в городах Поморья, они определили намерение выступить против тушинцев. Однако решительные действия по сбору ратных людей были предприняты приказными людьми Ф.П. Акинфовым и Н. Романовым лишь после прочтения 1 января 1609 г. государевой грамоты, хоть и не на свое имя.

В составе Соликамского архива сохранилась указная грамота царя Василия Шуйского галичанам от 30 ноября 1608 года [2, № 90, с. 183-184]. К этому времени до Москвы дошел слух о том, что галичане «неволею вором крест целовали». Грамота содержит возмущенное удивление измене галичан, призыв вспомнить свою православную веру и обещание «воровской смуте не верить», собираться в Ярославле с ратными людьми других городов и «очистить» Московское государство от «воров» [2, № 90, с. 183-184]. Текст грамоты написан в публицистическом стиле, ожидаемый эффект от нее усилен риторичес- 
кими вопросами. Грамота составлена «на Волоцкой дороге» за приписью Томилы Луговского - в тот момент он был думным дьяком Новгородского разряда [14, с. 129]. Факт доставки грамоты в Галич фиксируется в конце грамоты. Как видим, вести о событиях в разных городах страны осенью 1608 г. доходили до Москвы с опозданием: информация об отложении Галича дошла до царя спустя месяц, и даже спустя неделю после того, как Галич снова перешел на сторону В.И. Шуйского. Вполне очевидно, что на принятие решения галичан вернуться на службу к государю данная грамота В.И. Шуйского не повлияла галичане к моменту ее получения уже снова выступали в его защиту, но свою роль она сыграла в дальнейшем: распространяемая в виде списков в Поморье, грамота стала главным аргументом для приказных людей в процессе формирования ополчения. 1 января 1609 г. список с указной грамоты В.И. Шуйского от 30 ноября 1608 г. был доставлен через Соль Камскую в Чердынь к пермским приказным людям Федору Акинфову и Науму Романову [2, № 90, с. 184], и в тот же день в Перми Великой начался сбор ратных людей в поход для поддержки государя. Приказные служащие в городах, назначенные государем, действовали от его имени и всегда старались заручиться указной грамотой из Москвы [13].

В военных условиях противостояния царя и самозванца с осени 1608 г. регулярное сообщение со столицей было нарушено, приказные люди были вынуждены многие вопросы решать оперативно. Так, память пермского приказного человека Ф.П. Акинфова старосте Соли Камской В. Елисееву от 10 января 1609 г. начинается фразой: «...по государеву цареву и великого князя Василия Ивановича всея Русии указу...», и далее говорится, что 1 января 1609 г. из Соли Камской присылали челобитную на имя государя, в Чердынь, с просьбой дать взаймы денег на сбор ратных людей, и «по государеву указу из государевой казны дано взаймы... сто рублев». 10 января снова приехал челобитчик, так как денег не хватило, «и государь царь и великий князь Василей Иванович всеа Русии... усольцев... пожаловал, велел вам те денги шестьдесят рублев... дати» опять взаймы [1, № 133, c. 155]. То есть приказный человек Ф.П. Акин- фов, руководствуясь указной грамотой от 30 ноября 1608 г. и содержащимся в ней призывом, самостоятельно принял решение и от имени царя распорядился собранной государевой казной для организации выступления ратных людей в Ярославль, в поддержку Василия Шуйского, выдав взаймы 100 рублей из кабацких денег Усолья Камского и 60 рублей ратных денег, которые собирали в 1607/08 г., но в Москву не отправили.

17 января 1609 г. в отписке пермского приказного человека Ф.П. Акинфова И.Ф. Стрешневу на Устюг сообщалось, что неделей раньше, 8 января 1609 г., первые ратные люди из Перми Великой на помощь царю В.И. Шуйскому были отпущены, «собрали вдвое против прежнего государева указу» [1, № 138, с. 160]. Ф.П. Акинфов также написал о готовности выставить еще ратных людей по мере их сбора.

Стоит заметить, что по указу царя В.И. Шуйского от 10 декабря 1607 г., на 1608 г. ратных людей из Перми Великой отправлять в Москву было не велено по причине их дорогостоящего содержания, а следовало собрать взамен деньги для найма 70 ратных людей из других городов на три месяца «к зимнему походу» по два рубля на месяц $[1$, № 84, с. 113 ; 15 , с. 36-37]. Позже, к лету 1608 г., ситуация с заменой ратных людей на денежный сбор повторилась. По новой указной грамоте В.И. Шуйского, составленной в апреле - мае 1608 г., пермские приказные люди Ф.П. Акинфов и Н. Романов собрали в Соли Камской «для государевой службы за ратных людей» на три летних месяца «за усольской жеребей» за 10 человек по 2 рубля на человека [9; 15, с. 37-38].

20 января 1609 г. приказный человек Соли Вычегодской Поспел Извольский вместе с купцами Строгановыми отправили в Пермь Великую отписку с претензией по поводу бездействия и невыполнения обещания пермичей и вновь призвали собрать ратных людей и отправить на помощь государю В.И. Шуйскому [2, № 102, с. 199-201]. 26 января 1609 г. Поспел Извольский вместе с купцами Строгановыми подробно с указанием дат всей переписки сообщали в Устюг о бездействии пермских приказных людей, что пермские ратные люди мимо них «по сю пору... не прохаживали». Дополнительно приведено свидетельство человека Никиты Строганова Шу- 
милы Швеца, который был в Перми Великой и видел, что «никаких сборов ратных людей не ведется». В отписке вычегодцы обвинили пермичей в том, что написали отписку «мимо них» в Устюг и пишут «ложно, словом, а не делом», «чтоб им за другом пробыти» [1, № 143 , с. 165-166].

Указанные отписки были опубликованы и, исходя из этого, представления историков о происходивших событиях в Перми Великой в это время разделились. У С.М. Соловьева сложилось мнение о том, что в Перми Великой было промедление в ратном деле [19, с. $563-$ 564]. А.А. Дмитриев считал промедление следствием «отдаленности и затруднительного материального положения» и отметил, что «дух патриотизма» не был чужд в Перми Великой, а «воевода Акинфов... по мере возможности спешил... исполнением всех требований» $[3$, с. 85,89$]$. С.Ф. Платонов также объяснял промедление «бедностью и многозадачностью Пермского края ввиду его порубежного местоположения» [11, с. 304-305]. И.С. Шепелев отметил, что вычегодцы, обвиняя пермичей, были неправы, так как факт отправки ратных людей постоянно упоминается в отписках пермских приказных людей, и объяснил возникшую претензию тем, что «пермичи послали своих ратных людей не в Сольвычегодск, а в Устюг Великий» [24, с. 321]. Предположение И.С. Шепелева не может быть принято, так как в начале XVII в. миновать Соль Вычегодскую вряд ли бы получилось: путь к Москве проходил от Соли Камской на Кайгородок, затем на Соль Вычегодскую и далее на Великий Устюг [6]. Это подтверждается в отписках [2, № 110 (II), с. 212]. По мнению И.О. Тюменцева, население Устюга Великого и других городов Северного и Восточного Поморья, Сибири заняло выжидательную позицию [21, с. 255]. О.В. Семенов обозначил позицию региона в деле мобилизации ратников как двусмысленную: Пермь Великая «не последовала примеру многих областей государства, присягнувших Вору», но «не спешила и с оказанием помощи В. Шуйскому» [17, с. 39-40]. В то же время, оценивая различные ситуации в системе управления Пермью Великой, возникавшие на протяжении всей Смуты, историк не согласился с утверждением А.А. Дмитриева о связи безде- ятельности Перми Великой только с личной позицией Ф.П. Акинфова как «человека небольших способностей» (к этому А.А. Дмитриев пришел, анализируя в целом 1609 г.) [3, с. 109]. О.В. Семенов сделал заключение, что «подлинными хозяевами положения были “миры”» [17, с. 45]. Неопубликованные документы Соликамского архива позволяют внести ясность по этому вопросу.

19 января 1609 г. в Чердынь, административный центр Перми Великой, Ф.П. Акинфову и Н. Романову были доставлены две отписки. Первая - от старосты Соли Камской Васьки Елисеева [8], вторая - от соликамских десятников ратных людей Тихона Андреева и Гаврилы Корытова [7]. Из них мы узнаем, что 10 января 1609 г. из Соли Камской по распоряжению пермских приказных Ф.П. Акинфова и Н. Романова были отпущены в сбор с городами на помощь государю В.И. Шуйскому 20 ратных людей с «бережатым целовальником» Симоном Докшиным. Ф.П. Акинфов и Н. Романов дали подорожную грамоту, по которой им следовало взять подводы от Соли Камской до Устюга «без прогонов». В Кайгородке, также находившемся в административном подчинении Перми Великой, якобы по «научению кайгородских земских людей», их проводники сбежали, украв коней и ратное оружие - боевые луки, стрелы, самопалы, топоры и рогатины. Соликамские ратные люди пошли в судную кайгородскую избу просить по подорожным подвод, но староста и земские люди подвод не дали, сославшись на то, что подорожная не содержит указания кто, когда, откуда, куда идет, и смеялись над ней. Ратных людей назвали «ворами», а предъявленные отписки Ф.П. Акинфова и Н. Романова воеводам и наказная память шедшему с ними целовальнику действия не возымели. Староста Соли Камской и десятники спрашивали пермский приказных, что им дальше делать. 28 января 1609 г. Ф.П. Акинфов отписал кайгородскому земскому судье Терентию Дементьеву: «...и вы то делаете негораздо, что государевым ратным делом не радеете». По получении памяти им велено было дать подводы соликамским ратным людям по подорожной, собрать ратных людей с Кайгородка «тем же числом», что и с Соли Камской и отпустить к Устюгу Великому. Из 
Чердыни приказные администраторы обещали выдать им также на сбор ратных людей взаймы 60 рублей, которые были собраны на них в государеву казну в $1607 / 08$ году [1, № 142 (II), c. 164-165].

Таким образом, обмана со стороны приказного человека Ф.П. Акинфова и подьячего Наума Романова не было, как и промедления в сборе ратных людей. 1 января 1609 г. после получения списка с указной грамоты В.И. Шуйского в течение 10 дней в Соли Камской собрали 20 ратных людей, выделили им денег, оружие, и 10 января 1609 г. они вышли из Соли Камской. Ф.П. Акинфов во всех своих отписках указывал, что отправили ратных людей 8 января 1609 г. «вдвое против прежнего государева указу». Как видно по документам, речь идет об одних и тех же ратных людях, из Соли Камской, а не чердынцах, которые вышли и по какой-то причине никуда не дошли, как показано в работе А.А. Дмитриева [3, с. 87].

В дальнейшем становится ясно, что первые 20 человек соликамских ратных людей продолжили свой путь, к ним присоединились ратные люди из Кайгородка, также 20 человек, и, по свидетельству устюжан, они прошли Устюг «на масленой неделе» (20-26 февраля 1609 г. - H. Р.) [2, № 111, с. 214; № 110 (II), c. 211-212]. Факт промедления, определенно, присутствует, но он связан не с намеренной задержкой со стороны пермских приказных людей, а с возникшими по пути проблемами передвижения ратников.

К 1 марта 1609 г. ратных людей собрали и в Чердыни - 50 человек, привели к крестному целованью и отправили дорогой до Соли Вычегодской, затем на Устюг Великий и далее в государевы полки для соединения с пермскими людьми из Соли Камской и Кайгородка [2, № 110 (I), с. 211; № 110 (II), с. 211-212]. 8 марта 1609 г. пермичи написали об этом описку государю в Москву [2, № 110 (III), c. 212-213]. Со слов устюжан, 17 марта 1609 г. через Устюг Великий они еще не проходили [2, № 111, c. 214; № 110 (II), c. 211-212]. Но 21 марта 1609 г. до Вологды дошли 20 ратных людей из Соли Камской, 12 - из Кайгородка, 66 вымских ратных людей, о чем отписали в Пермь Великую вологжане [1, № 180, с. 209]. Таким образом, из Перми Великой в целом вышли 90 человек ратных людей, пришли в Вологду 96. Вероятно, указанные «вымские люди» - это и есть отправленные из Перми Великой чердынцы, так как ранее ни о каких вымских людях в документах не упоминается.

После 24 января 1609 г. в Перми Великой получили список со второй за рассматриваемый период указной грамоты царя В.И. Шуйского от 23 декабря 1608 г., адресованной в Устюжну Железнопольскую [2, № 93, с. 188-190]. Писал ее также от имени царя думный дьяк Новгородского разряда Томило Иудич Луговской «на стану на Волоцкой дороге». Грамота похожа по содержанию и употребляемым выражениям на первую грамоту, но не идентична. В грамоте содержится похвала духовенству и мирским людям всех сословий Устюжны Железнопольской за верность государю и призыв к действию - подняться всем городом, защищать свои земли от литовских людей, направить ратных людей в Ярославль для объединения сил разных городов и воеводы Ф.И. Шереметьева. Устюжанам велено было написать об этом «во все города», и если кто будет «изменные слова говорить» или идти не захочет, то им «делать наказанье», «кто чего достоин». Также более детально были расписаны будущие пожалования разным сословиям за верность В.И. Шуйскому. 24 января 1609 г. привез грамоту в Устюжну пристав Степанко Захарьин. Список с грамоты послали из Тотьмы на Устюг Великий с рассыльщиком Степанко Захарьиным [2, № 103 (I), c. 202].

В феврале - марте 1609 г. была сделана массовая рассылка государевых грамот о ратном и земском деле от царя В.И. Шуйского: в Устюг 2 грамоты - к приказному человеку И. Стрешневу и посадским людям (доставлены 16 марта 1609 г.), в Пермь Великую 2 грамоты - к приказному человеку Ф. Акинфову и к посадским людям (доставлены 25 марта 1609 г.), в Вятку, Соль Вычегодскую, Тотьму, на Вагу, на Двину «к приказным людям и к миру» [2, № 111, с. 213-214]. 26 марта 1609 г. список с государевой грамоты из Чердыни отправили в Кайгородок, а подлинную государеву грамоту - в Соль Камскую с распоряжением списать список и отправить обратно в Чердынь [1, № 179 (I), с. 208; № 179 (II), с. 208-209]. Вероятно, о таких же 
грамотах упоминают вологжане и пишут, что получили их 25 марта [1, № 180, с. 209].

4 апреля 1609 г. в Пермь Великую снова пришел запрос из городов на новых ратных людей и грамота князя и воеводы М.В. Скопин-Шуйского о необходимости идти на помощь государю [1, № 190, с. 221]. 11 апреля 1609 г. в Перми Великой получили грамоту от В.И. Шуйского, составленную на имя пермских приказных Ф.П. Акинфова и Н. Романова в феврале 1609 г. с тем же призывом - собирать ратных людей и отправлять к Вологде [2, № 106, с. 207-208].

Помимо организации ратной службы, второй вопрос системы управления касался государевой казны. Территория Перми Великой была в ведении Новгородского четвертного приказа. Доходы в государеву казну отправляли ежегодно по зимнему пути после получения соответствующей грамоты, содержащей разъяснение о том, как распорядиться государевой казной.

Государева казна за 1607/08 г. была собрана и 17 января 1609 г. приказный человек Перми Великой Ф.П. Акинфов интересовался у приказного человека Устюга Великого И.Ф. Стрешнева возможностью выслать ее и сметный список за 1607/08 г. в Москву устюжской дорогой $[1$, № 138, с. 160]. 25 января 1609 г. И.Ф. Стрешнев ответил, что дорога от Устюга до Вологды чиста, а «далее ехать нельзя, поэтому государеву казну посылать не поспешите» [1, № 141, с. 163].

Вместе с тем в Новгородском четвертном приказе дьяки Григорий Елизаров и Андрей Иванов составили 3 указные грамоты от имени царя В.И. Шуйского, адресованные пермским приказным людям. Они датированы 19 января 1609 г. [2, № 101, с. 198], 4 февраля 1609 г. [22], 19 февраля 1609 г. [23] Эти грамоты посвящены одному вопросу: каким образом следует осуществить организацию отправки в Сибирские города из Перми Великой хлебных запасов на жалованье сибирским служилым людям из собранной государевой казны и плотников на Верхотурье. Грамоты составлены в спокойном тоне, в каждой следующей идет отсылка к тексту предыдущей, никакой особой новой информации не добавляется, хотя они разные по объему - отличаются степенью детализации. Г. Елизарову и
А. Иванову было известно, что расстояние между Москвой и Пермью Великой в зимнее время преодолевалось обычно за 1 месяц в одну сторону. Это показывает анализ приказной переписки за 1607-1608 годы [15]. Можно предположить, что, отправляя грамоты с похожим содержанием и с разницей в 2 недели, дьяки учитывали существовавшие проблемы на дорогах и надеялись, что хотя бы какая-то из них дойдет до адресата. В мирное время писать грамоты с такими короткими промежутками времени по одному и тому же вопросу практики не было. В Пермь Великую эти грамоты дошли практически в одно время с разницей в 1 день: февральские привез из Соли Вычегодской Жданко Федоров 30 марта 1609 г., январскую - тобольский жилец Семен Кисель 31 марта 1609 года. Пометы о доставке есть на обороте самих грамот.

В целом за период с 1 января и до середины апреля 1609 г. в Перми Великой от имени царя В.И. Шуйского были получены 5 указных грамот из Новгородского разрядного приказа по вопросу сбора ратных людей и отправки к Москве для борьбы с тушинцами (1 адресована в Галич, 1 - в Устюжну Железнопольскую, 3 - в Пермь Великую) и 3 указные грамоты из Новгородского четвертного приказа в Пермь Великую о государевой казне и отправке хлеба в сибирские города на жалованье служилым людям.

Результаты. Анализ документов Соликамского архива подтверждает наблюдение, сделанное С.Ф. Платоновым о том, что «полной блокады Москвы не осуществилось» [11, c. 279]. Однако регулярное сообщение Москвы с городами Поморья было нарушено. Благодаря начавшемуся в декабре 1608 г. активному взаимодействию между городами, реализованному в земской переписке, удалось избежать информационного вакуума даже в отдаленных регионах северных территорий.

Прямые распоряжения верховной власти в указных грамотах В.И. Шуйского воспринимались приказными людьми в Перми Великой как руководство к действию. Приказный человек Федор Петрович Акинфов и подьячий Наум Романов старались исполнять распоряжения царя, но им это не всегда удавалось сделать так быстро, как от них ожи- 
далось. Нет оснований считать возникшее промедление с отправкой пермских ратных людей нежеланием приказных людей, назначавшихся из Москвы на 2-3 года, участвовать в поддержке царя В. Шуйского и земского движения. Промедление скорее было связано с отсутствием четкого административного управления на местном уровне: если в Соли Камской быстро отреагировали на запрос и выставили ратных людей, то в Кайгородке стали чинить препятствия не только в виде разбоя, но и на уровне мирского самоуправления.

\section{СПИСОК ЛИТЕРАТУРЫ}

1. Акты исторические, собранные и изданные Археографическою комиссиею : в 5 т. Т. $2: 1598$ 1613 гг. - СПб. : Тип. Экспедиции заготовления гос. бумаг, $1841 .-482 \mathrm{c}$.

2. Акты, собранные в библиотеках и архивах Российской империи археографическою экспедициею императорской академии наук : в 4 т. Т. 2. СПб. : в Тип. 2-го отд-ния Собственной Е.И.В. канцелярии, $1836 .-392 \mathrm{c}$.

3. Дмитриев, А. А. Первые годы после Ермака и Смутное время / А. А. Дмитриев // Пермская старина : сб. ист. ст. и материалов преимущественно о Пермском крае. - Вып. VI. - Пермь : Тип. П.Ф. Каменского, 1895. - С. 1-128.

4. Козляков, В. Н. Василий Шуйский / В. Н. Козляков. - М. : Молодая гвардия, 2007. -301 с.

5. Любомиров, П. Г. Очерк истории Нижегородского ополчения / П. Г. Любомиров // Подвиг Нижегородского ополчения. В 2 т. - Н. Новгород: Изд-во «Книги», 2011. - Т. 2. - С. 13-398.

6. Николаев, Ю. К. Большая «государева дорога» в Сибирь на участке от Кай-городка до Соликамска через села Юксеево и Коса / Ю. К. Николаев // География и туризм : сб. науч. тр. - Пермь : Б. и., 2011. - Вып. 10.-С. 73 - 88 .

7. Отписка Соли Камской ратных людей Тихона Андреева и Гаврилы Корытова с товарищами пермскому приказному Федору Петровичу Акинфову с известием о нежелании кайгородцев давать подводы соликамским ратным людям и о присылке распоряжения по этому поводу, 1609 г., между 11 и 18 января // Архив Санкт-Петербургского института истории Российской академии наук (СПбИИ РАН). - Кол. 122. - Оп.1. - № 153. - 2 л.

8. Отписка Соли Камской старосты Василия Елисеева пермскому приказному Федору Петровичу Акинфову о недаче кайгородцами подвод для ратных людей Соли Камской, 1609 г., 19 января // Архив СПбИИРАН. -Кол. 122. -Оп. 1.-№ 147. - 1 л.
9. Отписка соликамского старосты Ивана Никитина в Чердынь Федору Петровичу Акинфову и Науму Романову о посылке к ним денег за ратных людей, таможенного сбора, судных пошлин и целовальника с таможенными и кабацкими деньгами, 12 июля 1608 г. // Архив (СПбИИ РАН). - Кол. 122. Оп. 1. - № 114. -2 л.

10. Платонов, С. Ф. Лекции по русской истории / С. Ф. Платонов // Платонов С. Ф. Сочинения : в 2 т. Т. 1. - СПб., 1993. -734 с.

11. Платонов, С. Ф. Очерки по истории смуты в Московском государстве XVI-XVII вв. : (Опыт изучения общественного строя и сословных отношений в Смутное время) / С. Ф. Платонов. - 2-е изд. СПб. : Тип. И.Н. Скороходова, 1901. - 520 с.

12. Рыбалко, Н. В. Воеводская инициатива и подъем земского движения в конце 1608 г. (по материалам Соликамского архива) / Н. В. Рыбалко // Смутные времена в России начала XVII и начала XX столетий: природа и уроки. - Волгоград : Изд-во РАНХиГС, 2018.-С. 397-408.

13. Рыбалко, Н. В. Организация Соликамского яма и ямской службы в Перми Великой в 1607 году / Н. В. Рыбалко // Вестник Волгоградского государственного университета. Серия 4, История. Регионоведение. Международные отношения. - 2019. T. 24, № 2. - C. 120-136. - DOI: https://doi.org/ 10.15688/jvolsu4.2019.2.11.

14. Рыбалко, Н. В. Российская приказная бюрократия в Смутное время начала XVII века / Н.В. Рыбалко. - М. : МБА : Квадрига, 2011. - 656 с.

15. Рыбалко, Н. В. Соликамский архив: реконструкция и источниковедческий анализ (1605-1608 годы) / Н. В. Рыбалко, Е. Г. Дмитриева. - Волгоград : Изд-во ВолГУ, 2017. - 319 с.

16. Рыбалко, Н. В. Управление в Перми Великой конца XVI - начала XVII века: от приказных людей к воеводской власти / Н. В. Рыбалко // Вестник Волгоградского государственного университета. Серия 4, История. Регионоведение. Международные отношения. - 2020. - Т. 25, № 5. - С. 100112. - DOI: https://doi.org/10.15688/jvolsu4.2020.5.9.

17. Семенов, О. В. К вопросу о позиции Перми Великой в годы Смуты / О. В. Семенов // Мининские чтения : материалы науч. конф., Нижегородский государственный университет им. Н.И. Лобачевского (29-30 октября 2004 г.). - Н. Новгород : Изд-во Нижегород. ун-та, 2005. - С. 36-45.

18. Скрынников, Р. Г. Василий Шуйский / Р. Г. Скрынников. - М. : АСТ, 2002. -400 с.

19. Соловьев, С. М. История России с древнейших времен / С. М. Соловьев // Соловьев С. М. Сочинения. В 18 кн. Кн. IV. T. 8. - М. : Голос, 1994. $768 \mathrm{c}$.

20. Тюменцев, И. О. Русский архив Яна Сапеги 1608-1611 годов. Тексты, переводы, комментарии 
/ И. О. Тюменцев (рук.), Н. А. Тупикова, Н. Е. Тюменцева, Н. В. Рыбалко, С. В. Мирский. - Волгоград : Изд-во Волгогр. фил. РАНХиГС, 2012. - 688 с.

21. Тюменцев, И. О. Смута в России в начале XVII столетия: движение Лжедмитрия II / И. О. Тюменцев. - Волгоград : Изд-во ВолГУ, 1999. - 582 с.

22. Указная грамота в Пермь Великую приказным людям Федору Петровичу Акинфову и Науму Романову о сборе с Пермской земли хлебных запасов для отсылки в Сибирь на жалованье ратным людям и о посылке туда же плотников для постройки судов, 1609 г., 4 февраля // Архив СПбИИРАН. Кол. 122. - Оп. 1. - № 172. - 5 л.

23. Указная грамота в Пермь Великую приказным людям Федору Петровичу Акинфову и Науму Романову о сборе хлебных запасов и присылке их вместе с плотниками на Верхотурье, 1609 г., 19 февраля // Архив СПбИИ РАН. - Кол.122. - Оп.1. № $173 .-1$ л.

24. Шепелев, И. С. Освободительная и классовая борьба в Русском государстве в 1608-1610 гг. / И. С. Шепелев // Шепелев И. С. Труды по истории Смуты в России в начале XVII столетия : в 2 т. T. 2.Волгоград : Перемена, 2012. - 508 с.

\section{REFERENCES}

1. Akty istoricheskiye, sobrannye i izdannye Arkheograficheskoy komissieyu: v 5 t. T. 2: 1598$1613 \mathrm{gg}$. [Historical Acts, Collected and Published by the Archaeographic Commission. In 5 Vols. Vol. 2. 1598-1613]. Saint Petersburg, Tipografiya Ekspeditsii zagotovleniya gosudarstvennykh bumag, $1841.482 \mathrm{p}$.

2. Akty, sobrannye $v$ bibliotekach $i$ archivach Rossiyskoy imperii arkheograficheskoyu ekspeditsieyu imperatorskoy akademii nauk: v 4 t. T. 2 [Acts, Collected in Libraries and Archives of the Russian Empire by the Archaeographic Expedition of the Imperial Academy of Sciences]. Saint Petersburg, v Tipografii 2 otdeleniya Sobstvennoy Ye.I.V. kantselyarii, 1836. 392 p.

3. Dmitriev A.A. Pervye gody posle Ermaka i Smutnoye vremya [The First Years After Ermak and the Time of Troubles]. Permskaya starina: sb. ist. st. $i$ materialov preimushchestvenno o Permskom krae. Vyp. VI [Perm Antiquity: Collection of Historical Articles and Materials Mainly About Perm Krai. Issue VI]. Perm, Tipografiya P.F. Kamenskogo, 1885, pp. 1-128.

4. Kozlyakov V.N. Vasilij Shujskij [Vasily Shuisky]. Moscow, Molodaya Gvardiya, 2007. 301 p.

5. Lyubomirov P.G. Ocherk istorii Nizhegorodskogo opolcheniya [Essay on the History of the Nizhny Novgorod Militia]. Podvig Nizhegorodskogo opolcheniya. $V 2 t$., $t$. 2 [The Feat of the Nizhny Novgorod Militia. In 2 Vols. Vol. 2]. Nizhny Novgorod, Izd-vo «Knigi», 2011, pp. 1-398.
6. Nikolaev Yu.K. Bol'shaya «gosudareva doroga» v Sibir' na uchastke ot Kaj-gorodka do Solikamska cherez sela Yukseevo i Kosa [The Big "Sovereign's Road" to Siberia on the Section from KaiGorodok to Solikamsk Through the Villages of Yukseevo and Kos]. Geografiya i turizm: sb. nauch. tr. [Geography and tourism. Collection of Scientific Papers]. Perm, s.1., 2011, iss. 10. pp. 73-88.

7. Otpiska Soli Kamskoj ratnyh lyudej Tihona Andreeva i Gavrily Korytova s tovarishchami permskomu prikaznomu Fedoru Petrovichu Akinfovu s izvestiem o nezhelanii kajgorodcev davat' podvody solikamskim ratnym lyudyam i o prisylke rasporyazheniya po etomu povodu , $1609 \mathrm{~g}$., mezhdu 11 i 18 yanvarya [The Letter from the Solikamsk Military Men Tikhon Andreev and Gavrila Korytov with Comrades to the Perm Clerk Fedor Petrovich Akinfov with the News About the Reluctance of the Kaigorod People to Give Carts to the Solikamsk Military Men and to Send an Order on This Matter, 1609, Between January 11 and 18]. Arkhiv Sankt-Peterburgskogo instituta istorii Rossiyskoy akademii nauk [Archive of the Saint Petersburg Institute of History of the Russian Academy of Sciences], col. 122. op. 1. no. 153. 21.

8. Otpiska Soli Kamskoj starosty Vasiliya Eliseeva permskomu prikaznomu Fedoru Petrovichu Akinfovu o nedache kajgorodcami podvod dlya ratnyh lyudej Soli Kamskoj, 1609 g., 19 yanvarya [The Letter from the Solikamsk Elder Vasily Eliseev to the Perm Clerk Fedor Petrovich Akinfov About the Failure of the Kaigorod People to Supply Carts for Military Men of Solikamsk, 1609, January 19]. Arkhiv SanktPeterburgskogo instituta istorii Rossiyskoy akademii nauk [Archive of the Saint Petersburg Institute of History of the Russian Academy of Sciences], col. 122. op. 1. no. 147. 11 .

9. Otpiska solikamskogo starosty Ivana Nikitina v Cherdyn' Fedoru Petrovichu Akinfovu i Naumu Romanovu o posylke k nim deneg za ratnyh lyudej, tamozhennogo sbora, sudnyh poshlin i celoval'nika s tamozhennymi i kabackimi den'gami, 12 iyulya $1608 \mathrm{~g}$. [The Letter of the Solikamsk Mayor Ivan Nikitin in Cherdyn to Fedor Petrovich Akinfov and Naum Romanov About Sending Money to Them for Military Men, Customs Duty, Court Duties and a Kissing Man with Customs and Tavern Money, July 12, 1608]. Arkhiv Sankt-Peterburgskogo instituta istorii Rossiyskoy akademii nauk [Archive of the Saint Petersburg Institute of History of the Russian Academy of Sciences], col. 122. op. 1. no. 114. 21.

10. Platonov S.F. Lekcii po russkoj istorii [Lectures on Russian History]. Platonov S.F. Sochineniya: v 2 t. T. 1 [Works. In 2 Vols. Vol. 1]. Saint Petersburg, 1993. 734 p.

11. Platonov S.F. Ocherki po istorii smuty v Moskovskom gosudarstve XVI-XVII vv.: (Opyt 
izuchenija obshhestvennogo stroja i soslov. otnoshenij v Smutnoe vremja) [Essays on the History of Distemper in the Moscow State in $16^{\text {th }}-17^{\text {th }}$ Centuries: (Experience of the Study of the Social System and the Estate. Relations in the Time of Troubles)]. Saint Petersburg, Tipografiya I.N. Skorokhodova, 1901. 520 p.

12. Rybalko N.V. Voevodskaya iniciativa i podyem zemskogo dvizheniya v konce 1608 g. (po materialam Solikamskogo arhiva) [Voevodsk Initiative and the Rise of the Zemstvo Movement at the End of 1608 (Based on the Materials of the Solikamsk Archive)]. Smutnye vremena $v$ Rossii nachala XVII $i$ nachala XX stoletij: priroda $i$ uroki $[$ The Time of Troubles in Russia at the Beginning of the $17^{\text {th }}$ and Beginning of the $20^{\text {th }}$ Centuries: Nature and Lessons]. Volgograd, Izd-vo RANKhiGS, 2018, pp. 397-408.

13. Rybalko N.V. Organizatsiya Solikamskogo yama i yamskoy sluzhby v Permi Velikoy v 1607 godu [Organizing Solikamsk Coach Station and Coachman Service in Great Perm in 1607]. Vestnik Volgogradskogo gosudarstvennogo universiteta. Seriya 4, Istoriya. Regionovedenie. Mezhdunarodnye otnosheniya [Science Journal of Volgograd State University. History. Area Studies. International Relations], 2019, vol. 24 , no. 2 , pp. 120-136. DOI: https://doi.org/10. 15688/jvolsu4.2019.2.11.

14. Rybalko N.V. Rossiyskaya prikaznaya byurokratiya $v$ Smutnoe vremya nachala XVII veka [Russian Order Bureaucracy in the Time of Troubles in the Early $17^{\text {th }}$ Century]. Moscow, MBA Publ., Kvadriga Publ., 2011.656 p.

15. Rybalko N.V., Dmitrieva E.G. Solikamskij arhiv: rekonstrukcija i istochnikovedcheskij analiz (1605-1608 gody) [Solikamsk Archive: Reconstruction and Source Study Analysis (16051608)]. Volgograd, Izd-vo VolGU, 2017. 319 p.

16. Rybalko N.V. Upravlenie v Permi Velikoy kontsa XVI - nachala XVII veka: ot prikaznykh lyudey $\mathrm{k}$ voevodskoy vlasti [Great Perm Governance in the Late $16^{\text {th }}-$ Early $17^{\text {th }}$ Century: From Administrators to Voivodes]. Vestnik Volgogradskogo gosudarstvennogo universiteta. Seriya 4. Istoriya. Regionovedenie. Mezhdunarodnye otnosheniya [Science Journal of Volgograd State University. History. Area Studies. International Relations], 2020, vol. 25, no. 5, pp.100-112. DOI: https://doi.org/10.15688/jvolsu4.2020.5.9.

17. Semenov O.V. K voprosu o pozicii Permi Velikoj $\mathrm{v}$ gody Smuty [On the Question of the Position of Perm the Great During the Time of Troubles]. Mininskie Chteniya: materialy nauch. konf., Nizhegorodskij gosudarstvennyj universitet im. N.I. Lobachevskogo (29-30 oktyabrya 2004 g.) [Minin Readings. Proceedings of a Scientific Conference, Nizhny Novgorod State University named after N.I. Lobachevsky (October 29-30, 2004)]. Nizhny
Novgorod, Izd-vo Nizhegorodskogo universiteta, 2005 , pp. 36-45.

18. Skrynnikov R.G. Vasilij Shujskij [Vasily Shuisky]. Moscow, AST Publ., 2002. 400 p.

19. Solov'ev S.M. Istoriya Rossii s drevneyshikh vremen [History of Russia from Ancient Times]. Solov'ev S.M. Sochineniya. V 18 kn. Kn. IV. T. 8 [Works. In 18 Books. Book IV. Vol. 8]. Moscow, Golos Publ., 1994. 768 p.

20. Tyumentsev I.O., Tupikova N.A., Tyumentseva N.E., RybalkoN.V., Mirsky S.V.Russkij arhiv Yana Sapegi 1608-1611 godov. Teksty, perevody, kommentarii [Russian Archive of Yan Sapega 1608-1611. Texts, Translations, Comments]. Volgograd, Izd-vo Volgogradskogo filiala RANKhiGS, 2012.688 p.

21. Tjumencev I.O. Smuta v Rossii v nachale XVII stoletija: dvizhenie Lzhedmitrija II [The Time of Troubles in Russia at the Beginning of the $17^{\text {th }}$ Century: The False Dmitriy II Movement]. Volgograd, VolGU Publishing, 1999. 582 p.

22. Ukaznaya gramota v Perm' Velikuyu prikaznym lyudyam Fedoru Petrovichu Akinfovu i Naumu Romanovu o sbore s Permskoj zemli hlebnyh zapasov dlya otsylki v Sibir' na zhalovan'e ratnym lyudyam i o posylke tuda zhe plotnikov dlya postrojki sudov, 1609 g., 4 fevralya [A Decree to Perm the Great to the Clerks Fyodor Petrovich Akinfov and Naum Romanov on the Collection of Grain Reserves from the Perm Land for Sending to Siberia for Salaries to Military Men and on Sending Carpenters There to Build Ships, 1609, February 4]. Arkhiv SanktPeterburgskogo instituta istorii Rossiyskoy akademii nauk [Archive of the Saint Petersburg Institute of History of the Russian Academy of Sciences], col. 122. op. 1. no. 172.51 .

23. Ukaznaya gramota v Perm' Velikuyu prikaznym lyudyam Fedoru Petrovichu Akinfovu i Naumu Romanovu o sbore hlebnyh zapasov i prisylke ih vmeste s plotnikami na Verhotur'e, 1609 g., 19 fevralya [The Decree to the Great Perm to the Clerks Fedor Petrovich Akinfov and Naum Romanov About the Collection of Grain Reserves and Sending Them Together with Carpenters to Verkhoturye, 1609, February 19]. Arkhiv Sankt-Peterburgskogo instituta istorii Rossiyskoy akademii nauk [Archive of the Saint Petersburg Institute of History of the Russian Academy of Sciences], col. 122. op. 1. no. 173. 11.

24. Shepelev I.S. Osvoboditel'naja i klassovaja bor'ba v Russkom gosudarstve v 1608-1610 gg. [The Liberation and Class Struggle in the Russian State in 1608-1610]. Shepelev I.S. Trudy po istorii Smuty v Rossii $v$ nachale XVII stoletija: v 2 t. T. 2 [Works on the History of the Time of Troubles in Russia at the Beginning of the $17^{\text {th }}$ Century. In 2 Vols. Vol. 2]. Volgograd, Izd-vo VGSPU «Peremena», 2012. $508 \mathrm{p}$. 


\section{КРИЗИСНЫЕ ГОДЫ В ИСТОРИИ РОССИИ}

\section{Information About the Author}

Natalia V. Rybalko, Candidate of Sciences (History), Assistant Professor, Department of National and World History, Archaeology, Volgograd State University, Prosp. Universitetsky, 100, 400062 Volgograd, Russian Federation, natalia.rybalko@volsu.ru, rybalko_n@mail.ru, https://orcid.org/0000-0002-5141-0902

\section{Информация об авторе}

Наталия Владимировна Рыбалко, кандидат исторических наук, доцент кафедры отечественной и всеобщей истории, археологии, Волгоградский государственный университет, просп. Университетский, 100, 400062 г. Волгоград, Российская Федерация, natalia.rybalko@volsu.ru, rybalko_n@mail.ru, https://orcid.org/0000-0002-5141-0902 